\title{
THE INFLUENCE OF VACCINATION AGAINST TUBERCULOSIS WITH THE BACILLUS-CALMETTE-GUÉRIN (BCG) VACCINE ON COVID-19 INCIDENCE AND MORTALITY - A REVIEW OF THE LITERATURE
}

\author{
WPŁYW SZCZEPIENIA PRZECIWKO GRUŹLICY SZCZEPIONKĄ \\ BACILLUS-CALMETTE-GUÉRIN (BCG) NA ZACHOROWALNOŚĆ I UMIERALNOŚĆ \\ Z POWODU COVID-19 - PRZEGLĄD LITERATURY
}

\author{
'Medical University of Lublin, Students' Scientific Association of Chair and Department of Epidemiology \\ and Clinical Research Methodology \\ ${ }^{2}$ Medical University of Lublin, Chair and Department of Epidemiology and Clinical Research Methodology \\ ${ }^{1}$ Uniwersytet Medyczny w Lublinie, Studenckie Koło Naukowe przy Katedrze i Zakładzie Epidemiologii \\ i Metodologii Badań Klinicznych \\ ${ }^{2}$ Uniwersytet Medyczny w Lublinie, Katedra i Zakład Epidemiologii i Metodologii Badań Klinicznych
}

\begin{abstract}
THE AIM OF THE STUDY. Is to present the state of knowledge from April and May 2020 about the influence of Bacillus-Calmette-Guérin vaccination against tuberculosis on incidence and mortality due to COVID-19.

MATERIAL AND METHODS. A review of the latest literature till 9 May 2020 has been made. PubMed and ResearchGate databases and WHO reports were used.

RESULTS. Immunomodulatory properties of the tuberculosis vaccine which protects against severe cases of tuberculosis and partly against other infections are indicated, including viral and respiratory infections. The BCG vaccine induces heterologous immunity and trained innate immunity. It was noted that in countries which maintain obligatory BCG vaccination COVID-19 incidence and mortality are lower than in countries that have stopped or never introduced BCG as mandatory vaccination. Most analysis confirmed this relationship, but they indicated the possible impact of other factors, such as genetics in the population, the type of strain from BCG vaccine, the level of health care and the wealth of a nation, the structure of migration, co-morbidities and a policy of introducing social distance.

CONCLUSIONS. At the moment, we do not have enough evidence to support or deny the hypothesis of COVID-19 reduction in incidence and mortality in countries maintaining obligatory BCG vaccination. Other factors that might affect the results should be considered in further analysis. The results of clinical trials will provide more reliable proofs than analysis of epidemiological data. WHO does not recommend BCG vaccination to prevent COVID-19 and recommends it to newborns from areas with a higher incidence of tuberculosis.
\end{abstract}

Key words: $B C G$ vaccine, COVID-19, SARS-CoV-2

\section{STRESZCZENIE}

CEL. Celem pracy jest przedstawienie stanu wiedzy z przełomu kwietnia i maja 2020 roku na temat wpływu szczepienia przeciwko gruźlicy Bacillus-Calmette-Guérin na zachorowalność i umieralność z powodu COVID-19.

MATERIAŁ I METODY. Dokonano przeglądu najnowszej dostępnej literatury do dnia 09.05.2020 roku. Korzystano z baz danych PubMed i ResearchGate oraz doniesień Światowej Organizacji Zdrowia.

WYNIKI. Wskazuje się na immunomodulujące właściwości szczepionki BCG, która chroni przed najcięższymi przypadkami gruźlicy oraz częściowo przed innymi zakażeniami, w tym wirusowymi i wywołującymi zakażenia układu oddechowego. Szczepionka ta indukuje odporność heterologiczną i w mechanizmie „wy-

(C) National Institute of Public Health - National Institute of Hygiene / Narodowy Instytut Zdrowia Publicznego - Państwowy Zakład Higieny 
uczonej" odporności wrodzonej. Zauważono, że w krajach, które utrzymują obowiązkowe szczepienie BCG w dzieciństwie, zachorowalność i umieralność z powodu COVID-19 jest niższa niż w krajach, które zaprzestały obowiązkowych szczepień lub ich nigdy nie wprowadziły. Większość analiz potwierdziła tę zależność, jednak wskazały one jednocześnie na możliwy wpływ innych czynników zakłócających wyniki, takich jak czynniki genetyczne w populacji, rodzaj szczepu bakteryjnego użytego do wykonania szczepionki BCG, poziom opieki zdrowotnej i zamożności narodu, struktura migracji, choroby współistniejące pacjentów z COVID-19 i polityka wprowadzania dystansu społecznego.

WNIOSKI. Obecnie nie ma wystarczających dowodów, by potwierdzić lub zaprzeczyć postawionej hipotezie obniżenia zachorowalności i umieralności z powodu COVID-19 w krajach utrzymujących obowiązkowe szczepienie BCG. Inne czynniki mogące mieć wpływ na wyniki należy wziąć pod uwagę w dalszych analizach. Wyniki badań klinicznych dostarczą bardziej wiarygodnych dowodów niż analizy danych epidemiologicznych. Światowa Organizacja Zdrowia nie zaleca obecnie szczepienia BCG w celu zapobiegania COVID-19 i zaleca je jak dotychczas noworodkom z terenów o wyższej zachorowalności na gruźlicę.

Słowa kluczowe: szczepionka BCG, COVID-19, SARS-CoV-2

\section{INTRODUCTION}

BCG vaccine (Bacillus-Calmette-Guérin) is a vaccine invented at the beginning of the 20th century by Albert Calmette and Camille Guérin. It protects not only against the most severe tuberculosis, like miliary tuberculosis and tuberculous encephalomyelitis, but it also shows some efficacy in protection against leprosy. Also, it is used in the immunotherapy of a non-muscleinvasive bladder cancer $(1,2,3,4)$. The heterologous partial protective effect of BCG vaccine against other previously known infections, including viral and respiratory infections, is postulated $(1,2,3,4,5,6,7)$.

The outbreak of the SARS-CoV-2 coronavirus pandemic has prompted the search for factors that affect morbidity and mortality from a new disease. It was noted that in countries where the vaccination against tuberculosis is compulsory (for example Japan, South Korea, Central and Eastern European Countries), COVID-19 mortality is lower than in countries where the vaccination is not compulsory (for instance the United States, Italy) which may be influenced by the immunomodulatory properties of the vaccine on the innate immune response $(8,9,10,11,12)$. At the same time, it is pointed out that this state of affairs may be affected by a number of other factors, such as the level of health care, genetic factors in a population, its demographic structure, population density, commercial relations, even hepatitis B vaccination is considered. Therefore, at present, the above hypothesis can be neither confirmed nor certainly denied $(10,11)$. The authors of the study also indicate that the impact of various factors on COVID-19 mortality is so large that it is not possible to conclude from the analysis of merely morbidity and mortality data about the effect of BCG vaccination on their values (13). Currently, clinical trials are underway to verify the hypothesis $(1,9,12)$.

\section{WSTĘP}

Szczepionka BCG (Bacillus-Calmette-Guérin) jest szczepionką opracowaną na początku XX wieku przez Alberta Calmette'a i Camille'a Guérina. Chroni ona nie tylko przed najcięższymi postaciami gruźlicy, jak gruźlicą prosówkową i gruźliczym zapaleniem opon mózgowo-rdzeniowych, lecz także wykazuje pewną skuteczność w ochronie przed trądem oraz jest używana w immunoterapii raka pęcherza moczowego niepenetrującego do mięśni $(1,2,3,4)$. Postuluje się heterologiczne częściowe działanie ochronne szczepionki BCG w stosunku do innych znanych wcześniej zakażeń, w tym wirusowych i powodujących zakażenia dróg oddechowych $(1,2,3,4,5,6,7)$.

Wybuch pandemii koronawirusa SARS-CoV-2 skłonił do poszukiwań czynników wpływających na zachorowalność i umieralność na nową chorobę. Zauważono, że w krajach, w których szczepienie przeciwko gruźlicy jest obowiązkowe (m.in. Japonia, Korea Południowa, kraje Europy Środkowo-Wschodniej), umieralność z powodu COVID-19 jest niższa niż w krajach, w których to szczepienie obowiązkowe nie jest (m.in. Stany Zjednoczone, Włochy), na co mogą mieć wpływ właściwości immunomodulujące szczepionki na wrodzoną odpowiedź immunologiczną $(8,9,10,11,12)$. Wskazuje się jednocześnie, że na taki stan rzeczy może wpływać szereg innych czynników, jak poziom opieki zdrowotnej, czynniki genetyczne w danej populacji, jej struktura demograficzna, zagęszczenie ludności, stosunki handlowe, nawet brane jest pod uwage szczepienie przeciwko WZW B. Nie można więc na chwilę obecną potwierdzić powyższej hipotezy ani z całą pewnością jej zaprzeczyć $(10,11)$. Autorzy badań zaznaczają również, że wpływ różnorakich czynników na umieralność z powodu COVID-19 jest tak duży, że nie można z samej analizy danych dotyczących zachorowań i umieralności wnioskować o wpływie szczepienia BCG na ich warto- 


\section{THE AIM OF THE STUDY}

The aim of the study is to present the state of knowledge from the turn of April and May 2020 about the influence of Bacillus-Calmette-Guérin vaccination against tuberculosis on the incidence and mortality rate due to COVID-19.

\section{MATERIAL AND METHODS}

A review of the latest literature till 9 May 2020 has been made. PubMed and ResearchGate databases and World Health Organization reports were used.

\section{RESULTS}

\section{Modulation of the immune system by BCG vaccine}

Not only does vaccination against tuberculosis with $B C G$ vaccine protect against the most severe forms of tuberculosis itself, but also it has other beneficial effects not directly related to protection against this disease. It reduces the mortality rate in childhood, mainly due to a decrease in the incidence of septic and respiratory infections $(1,2,4,5,6)$. The protective effect of BCG may not be directly related to the effect of SARS-CoV-2, but on accompanying co-morbid infections, including septic ones (8). It is indicated that there is a molecular similarity between BCG vaccine antigens and viral antigens, which can lead to the formation of B and T memory cells recognizing both Mycobacterium tuberculosis and respiratory viral pathogens. This vaccination may lead to antigen-independent activation of $\mathrm{B}$ and $\mathrm{T}$ lymphocytes recognizing the epitope of another antigen through a mechanism called heterologous immunity $(1,2,5,7)$. The BCG vaccine may have a protective effect against infections with both DNA and RNA viruses (influenza virus, viruses of the Herpesviridae family) (7). It can also lead to long-term activation, reprogramming cells of the innate immune response and the development of a certain type of immune memory (so-called "trained immunity"). BCG vaccination induces histone methylation modification and epigenetic reprogramming of human monocytes at promoter sites of genes encoding proinflammatory cytokines $(1,2,6,7,8,9)$. These changes lead either to the expression or inhibition of genes that increase the intensity of the immune response (better pathogen recognition, faster inflammatory response) compared to infections other than with Mycobacterium tuberculosis (6). Compared with adult monocytes who did not receive the BCG vaccine, in adults who received the BCG vaccine monocytes show increased expression of surface markers associated with the activation and production ści (13). Aktualnie rozpoczynane sa badania kliniczne mające zweryfikować postawioną hipotezę $(1,9,12)$.

\section{CEL PRACY}

Celem pracy jest ukazanie stanu wiedzy z przełomu kwietnia i maja 2020 roku na temat wpływu szczepienia przeciwko gruźlicy na zachorowalność i umieralność z powodu COVID-19.

\section{MATERIAŁ I METODY}

Dokonano przeglądu dostępnej literatury z ostatnich 5 lat do dnia 9.05.2020 roku. Korzystano z baz danych PubMed i ResearchGate oraz doniesień Światowej Organizacji Zdrowia.

\section{WYNIKI}

\section{Modulacja ukladu odpornościowego przez szcze- pionkę BCG}

Szczepienie przeciwko gruźlicy szczepionką BCG chroni nie tylko przed najcięższymi postaciami samej gruźlicy, lecz posiada również inne korzystne efekty niezwiązane bezpośrednio $\mathrm{z}$ ochroną przed tą chorobą. Zmniejsza współczynnik umieralności w dzieciństwie, głównie z powodu zmniejszenia zapadalności na zakażenia septyczne i infekcje układu oddechowego $(1,2,4,5,6)$. Ochronny wpływ BCG może nie być bezpośrednio związany z działaniem na SARS-CoV-19, lecz na towarzyszące współistniejące zakażenia, w tym septyczne (8). Wskazuje się, że istnieje podobieństwo molekularne między antygenami ze szczepionki BCG i antygenami wirusowymi, co może prowadzić do powstania komórek pamięci B i T rozpoznających zarówno prątki gruźlicy, jak i patogeny wirusowe atakujące układ oddechowy. Szczepienie to może prowadzić do niezależnej od antygenu aktywacji limfocytów B i T rozpoznających epitop innego antygenu $\mathrm{w}$ mechanizmie nazywanym odpornością heterologiczną $(1,2,5,7)$. Szczepionka BCG może mieć działanie ochronne przed zakażeniami zarówno DNA, jak i RNA wirusami (wirusem grypy, z rodziny Herpesviridae) (7). Może także doprowadzić do długoterminowej aktywacji, przeprogramowania komórek wrodzonej odpowiedzi immunologicznej i wykształcenia się pewnego rodzaju pamięci immunologicznej (tzw. "wyuczona" odporność - trained immunity). Szczepienie BCG indukuje modyfikacje $\mathrm{w}$ metylacji histonów i epigenetyczne przeprogramowanie ludzkich monocytów w miejscach promotora genów kodujących cytokiny prozapalne $(1,2,6,7,8,9)$. Zmiany te prowadzą do ekspresji bądź hamowania genów zwiększających intensywność odpowiedzi immunologicznej (lepsze rozpoznanie patogenu, szybsza odpowiedź zapalna) w stosunku do zakażeń innych 
of proinflammatory cytokines (IL-1 $\beta$, IL-6, IFN $\gamma$ and TNF) in response to infection $(1,2,4)$. IL-1 $\beta$ plays a significantly important role $(2,8)$. It is pointed out that, apart from monocytes, NK (natural killers) cells are also involved in the creation of the mentioned cross-resistance in the mechanism of "trained" innate immunity $(3,4,6)$. Some researchers recommend the use of multiple intradermal BCG vaccinations in clinical trials (at least 2 doses 4 weeks apart) as a potentially better protection against COVID-19 (3).

According to conducted studies, COVID-19 infection in BCG vaccinated individuals may cause sudden expansion and activation of NK cells leading to cytokine production, providing independent protection for $\mathrm{T}$ cells. BCG vaccination promotes innate immune memory and induces adaptive immune response with CD4+ and CD8+ $\mathrm{T}$ cell activation and increased INF- $\gamma$ production. It is probable that an earlier BCG vaccination status may result in higher IFN- $\gamma$ levels that can prevent $T$ cell migration into the lungs and reduce inflammatory tissue damage which enables better recovery (10). BCG vaccination affects the cytokine response to toll-like receptors ligands (TLRs) and pathogens other than M. tuberculosis, which is characterized by a reduced anti-inflammatory response of cytokines and chemokines in the context of higher IL-6 levels (10).

BCG may elicit non-specific responses to infection at the level of both trained immunity and heterologous Th1/Th17 responses by prolonged production of IFN- $\gamma$, IL-17 and IL-22. This non-specific protective effect consists of innate immune response cells such as monocytes and NK cells (11).

The components of the BCG vaccine may remain viable after subcutaneous administration for several months, which contributes to the production of B and $\mathrm{T}$ memory cells not only against $\mathrm{M}$. tuberculosis, but it also stimulates innate immune response cells such as macrophages, NK cells and neutrophils. Studies have shown that leukocytes of the innate immune response can neutralize up to $99 \%$ of pathogens entering the body (12). A 2014 review ordered by the World Health Organization concluded that BCG vaccine appears to reduce overall child mortality, but estimates confidence in results as low (12). A randomized study made in 2018 showed that BCG protects against experimentally-induced infection with a weakened yellow fever virus $(1,2,12)$. niż prątek gruźlicy (6). U dorosłych, którzy otrzymali szczepionkę BCG, monocyty wykazują zwiększoną ekspresję markerów powierzchniowych związanych z aktywacją i produkcją cytokin prozapalnych (IL-1 $\beta$, IL-6, IFN $\gamma$ i TNF) w odpowiedzi na zakażenie w porównaniu z monocytami dorosłych, którzy nie otrzymali szczepionki BCG $(1,2,4)$. Szczególnie dużą rolę przypisuje się interleukinie IL-1 $\beta(2,8)$. Wskazuje się na udział, poza monocytami, także komórek NK (natural killers) w tworzeniu wspomnianej odporności krzyżowej w mechanizmie "wyuczonej" wrodzonej odporności $(3,4,6)$. Część badaczy zaleca zastosowanie w badaniach klinicznych kilkukrotnego śródskórnego szczepienia BCG (co najmniej 2 dawki w odstępie 4 tygodni) jako potencjalnie lepiej chroniących przed zachorowaniem na COVID-19 (3).

Według przeprowadzonych badań infekcja COVID-19 u osób szczepionych BCG może wywołać nagłą ekspansję i aktywację komórek NK prowadzącą do produkcji cytokin, zapewniając niezależną ochronę limfocytów T. Szczepienie BCG promuje wrodzoną pamięć immunologiczną oraz indukuje adaptacyjną odpowiedź immunologiczną z aktywacją komórek T CD4+ i CD8+ oraz podwyższoną produkcją INF- $\gamma$. Prawdopodobne jest, że wcześniejszy stan zaszczepienia BCG może skutkować wyższym poziomem IFN- $\gamma$, który może zapobiec migracji komórek $\mathrm{T}$ do płuc i zmniejszać uszkodzenia tkanek przez stany zapalne, umożliwiając sprawniejszy powrót do zdrowia (10). Szczepienie BCG wpływa na odpowiedź cytokin na ligandy receptorów toll-podobnych (TLR) i innych niż M. tuberculosis patogenów, co charakteryzuje się zmniejszoną odpowiedzią przeciwzapalną cytokin i chemokin w kontekście wyższych poziomów IL-6 (10).

BCG może wywoływać niespecyficzne reakcje na infekcje na poziomie zarówno "wyuczonej" odporności, jak i heterologicznej odpowiedzi Th1/Th17 przez przedłużone wytwarzanie IFN- $\gamma$, IL-17 i IL-22. Na ten niespecyficzny protekcyjny efekt składają się komórki wrodzonej odpowiedzi immunologicznej, takie jak monocyty i komórki NK (11).

Składniki szczepionki BCG mogą pozostać żywe po podaniu pod skórę przez kilka miesięcy, co przyczynia się do produkcji komórek pamięci B i T nie tylko przeciw M. tuberculosis, ale również stymuluje komórki wrodzonej odpowiedzi immunologicznej, jak makrofagi, komórki NK i neutrofile. Prace ukazały, iż leukocyty wrodzonej odpowiedzi immunologicznej mogą unieszkodliwiać nawet $99 \%$ patogenów dostających się do ciała (12). W przeglądzie z 2014 r. zleconym przez Światową Organizację Zdrowia stwierdzono, że szczepionka BCG wydaje się obniżać ogólną umieralność dzieci, ale zaufanie do wyników oceniono jako niskie (12). W randomizowanym badaniu wykonanym w 2018 r. ukazano, 
The effect of BCG vaccination on morbidity and mortality from SARS-CoV-2 infection

It has been noted that the outbreak of the new SARS-CoV-2 coronavirus epidemic has taken on varying degrees of severity across countries. The hypothesis has been made that this state of affairs may be partly influenced by the maintenance or withdrawal of mandatory vaccination against BCG tuberculosis in childhood in the country $(8,9)$.

A comparison of morbidity and mortality data in many countries with different BCG vaccination policies was made. Countries with populations above 1 million were included, and they were divided according to wealth to exclude from the analysis countries that did not perform enough tests (8). Analysis of data from 21 March 2020 showed that countries that did not introduce compulsory BCG vaccinations (Italy, USA, Lebanon, the Netherlands, Belgium) were more seriously affected by the epidemic compared to countries with a long history of vaccination (Japan). In countries that mandatory BCG vaccination was introduced relatively late (Iran, 1984), quite high mortality has been demonstrated, which presumably may be associated with the fact that people over 36 years old are potentially unvaccinated (8). It was noted that COVID-19 mortality rate increased with age and the earlier countries introduced compulsory vaccinations, the greater part of the older population can now be protected. Iran which has had mandatory BCG vaccinations since 1984, has a higher mortality rate (19.7 deaths per million inhabitants) than Japan which introduced compulsory vaccinations in 1947 ( 0.28 deaths per million inhabitants) and Brazil where widespread vaccination has been noted since 1920 and has even lower mortality rate, which is 0.0573 deaths per million inhabitants (8). Analysis showed a statistically significant relationship between the year of introduction and withdrawal of universal BCG vaccination and COVID-19 mortality, as seen in Spain and Denmark. In Spain (1965-1981, 16 years) there was a higher mortality rate (29.5 deaths per million inhabitants) than in Denmark (1946-1986, 40 years), which had 10 times less deaths ( 2.3 deaths per million inhabitants). The earlier the country introduced compulsory BCG vaccination, the lower the number of deaths per million inhabitants it presented, hence the suggestion that protecting the elderly population may play a key role in reducing mortality (8).

Another analysis compared data on morbidity and mortality per 1 million people from all countries from at least 500 (23 March 2020) or 1,000 cases (29 and 31 March 2020) (9). The number of new cases per million in countries with compulsory BCG vaccinations was statistically significantly lower than in those who stopped or never introduced national BCG vaccination że BCG chroni przed eksperymentalnie wywołaną infekcją osłabionym wirusem żółtej gorączki $(1,2,12)$.

\section{Wpływ szczepienia BCG na zachorowalność i umie- ralność $\mathrm{z}$ powodu zakażenia wirusem SARS-CoV-2}

Zauważono, że epidemia nowego koronawirusa SARS-CoV-2 przybrała różne nasilenie w poszczególnych krajach. Wysnuto hipotezę, że na ten stan rzeczy może częściowo wpływać utrzymanie bądź nie w kraju obowiązkowego szczepienia przeciwko gruźlicy BCG w dzieciństwie $(8,9)$.

Dokonano porównania danych zachorowalności i umieralności w wielu krajach o różnej polityce szczepienia BCG. Uwzględniono kraje o liczbie ludności powyżej 1 miliona oraz podzielono je według zamożności, by wykluczyć z analizy kraje wykonujące niedostateczną liczbę testów (8). Analiza danych z 21.03.2020 roku pokazała, że kraje, które nie wprowadziły obowiązkowych szczepień BCG (Włochy, USA, Liban, Holandia, Belgia), zostały poważniej dotknięte epidemią w porównaniu z krajami o długoletniej historii szczepień (Japonia). W krajach, które stosunkowo późno wprowadziły obowiązkowe szczepienia BCG (Iran, 1984), wykazano dość wysoką umieralność, co przypuszczalnie może się wiązać z tym, że osoby powyżej 36. roku życia są potencjalnie niezaszczepione (8). Zwrócono uwagę, że umieralność z powodu COVID-19 zwiększała się z wiekiem, a im wcześniej kraje wprowadziły obowiązkowe szczepienia, tym większa część starszej populacji może być obecnie chroniona. Iran, mający obowiązkowe szczepienia BCG od 1984 roku, ma wyższą umieralność (19,7 zgonów na milion mieszkańców) niż Japonia, która wprowadziła obowiązkowe szczepienia w 1947 r. ( 0,28 zgonów na milion mieszkańców) i Brazylia, która rozpoczęła powszechne szczepienia w $1920 \mathrm{r}$. i ma jeszcze niższą umieralność wynoszącą 0,0573 zgonów na milion mieszkańców (8). Analizy wykazały istotną statystycznie zależność między rokiem wprowadzenia i wycofania powszechnego szczepienia BCG a umieralnością z powodu COVID-19, co widać na przykładzie Hiszpanii i Danii. W Hiszpanii (1965 - 1981, 16 lat) odnotowano wyższą umieralność $(29,5$ zgonów na milion mieszkańców) niż w Danii (1946 - 1986, 40 lat), w której odnotowano 10-krotnie mniej zgonów (2,3 zgonu na milion mieszkańców) (8). Im wcześniej kraj wprowadził obowiązkowe szczepienie BCG, tym prezentował mniejszą liczbę zgonów na milion mieszkańców, stąd sugestia, że ochrona populacji osób starszych może mieć kluczowe znaczenie w zmniejszaniu umieralności (8).

W innej analizie porównano dane dotyczące zachorowalności i umieralności na 1 milion osób ze wszystkich krajów z co najmniej 500 (23.03.2020 r.) lub 1000 przypadków (29 i 31.03.2020 r.) (9). Liczba nowych przypadków na milion w krajach $\mathrm{z}$ obowiązkowymi 
programs. For each of analyzed days COVID-19 mortality in relation to population in a particular country was significantly lower in the countries covered by the compulsory BCG vaccination program than in countries not covered by it (9). The different times of epidemic outbreak in particular countries were also taken into account and correlations were checked for one outbreak moment. There was a very significant difference between countries that had universal BCG vaccination programme and countries that stopped or never entered it in the compulsory immunization schedule (9). Further, results showed a statistically significant reduction in the number of deaths per million people on the seventh day of the epidemic between countries that have stopped BCG vaccination in the last 2 decades (Norway, France, Finland, United Kingdom, Germany) compared to those that have ceased earlier, in the last 3-4 decades (Austria, Belgium, Switzerland, Denmark, Spain, the Netherlands, Sweden). These data would support the hypothesis that heterologous protective effect of vaccination against tuberculosis decreases after 20 years (9). Mayda Gursel and Ihsan Gursel suggest that BCG vaccination could potentially give partial protection against COVID-19 until the invention of the vaccine against SARS-CoV-2. The effect of BCG vaccination on COVID-19 morbidity and mortality may depend on the type of strain which is present in the vaccine. Studies have shown that protection against tuberculosis induced by newer BCG vaccine strains (Iran, China), containing less methoxymycolic acids, is shorter in comparison to older strains commonly used in other countries (Russia, Japan) (9).

The analysis of data from 16 April 2020 shows that the average number of COVID-19 cases per population (n) as well as mortality is statistically significantly lower in countries with compulsory BCG vaccination $(\mathrm{n}=138)$ compared to countries with noncompulsory BCG vaccination $(n=37)(11)$. After dividing the countries by their location in the globe, it was found that the average rate of cases per population is higher in the Northern Hemisphere $(\mathrm{n}=144)$ compared to southern countries ( $\mathrm{n}$ $=31$ ) and the death rate has the same distribution (11). Comparing individual countries north of the equator, the incidence rate was significantly lower in countries with compulsory BCG vaccine $(n=109)$ compared to countries without obligatory vaccination $(n=35)$. The death rate followed the same trend (11). In Europe the average number of cases per population is much lower in the countries which population was vaccinated with BCG $(n=25)$ compared to those where population was not vaccinated $(\mathrm{n}=26)(11)$.

Other factors mentioned in the study that may affect COVID-19 morbidity and mortality apart from BCG vaccination include population density, isolation szczepieniami BCG była istotnie statystycznie niższa niż w tych, które zaprzestały lub nigdy nie wprowadziły krajowych programów szczepień BCG. Dla każdego $\mathrm{z}$ analizowanych dni umieralność $\mathrm{z}$ powodu COVID-19 w odniesieniu do liczby ludności w danym kraju była znacznie niższa $\mathrm{w}$ krajach objętych obowiązkowym programem szczepień BCG niż w krajach nieobjętych nim (9). Wzięto także pod uwagę różny czas początku epidemii w poszczególnych krajach i sprawdzano zależności dla jednego momentu epidemii. Istniała bardzo znacząca różnica między krajami, które posiadały obowiązkowe szczepienia BCG a krajami, które zaprzestały lub nigdy nie wprowadziły ich do kalendarza szczepień obowiązkowych (9). W dalszych analizach wykazano statystycznie istotne zmniejszenie liczby zgonów na milion osób w siódmym dniu epidemii między krajami, które zaprzestały szczepień BCG w ciągu ostatnich 2 dekad (Norwegia, Francja, Finlandia, Wielka Brytania, Niemcy) w porównaniu do tych, które zrezygnowały wcześniej, w ostatnich 3-4 dekadach (Austria, Belgia, Szwajcaria, Dania, Hiszpania, Holandia, Szwecja). Dane te potwierdzałyby hipotezę, że heterologiczna odporność po szczepieniu przeciwko gruźlicy po 20 latach zmniejsza się (9). Mayda Gursel i Ihsan Gursel sugerują, że szczepienie BCG mogłoby potencjalnie dawać częściową ochronę przed COVID-19 do czasu wynalezienia szczepionki przeciwko SARSCoV-2. Wpływ szczepienia BCG na zachorowalność i umieralność z powodu COVID-19 może zależeć od rodzaju szczepu obecnego w szczepionce. W badaniach wykazano, że odporność na gruźlicę indukowana przez nowsze szczepy szczepionkowe BCG (Iran, Chiny), zawierające mniej kwasów metoksymykolowych, utrzymuje się krócej w porównaniu ze starszymi szczepami powszechnie stosowanymi w innych krajach (Rosja, Japonia) (9).

Analiza danych z dnia 16.04.2020 r. ukazuje, że średnia liczba przypadków COVID-19 na populację (n), jak również umieralność jest statystycznie istotnie niższa w krajach z obowiązkowym ( $\mathrm{n}=138)$ w porównaniu z krajami z nieobowiązkowym szczepieniem BCG $(n=37)$ (11). Po podziale krajów według ich lokalizacji na półkuli ziemskiej stwierdzono, że średni wskaźnik zachorowań na populację jest wyższy w krajach półkuli północnej $(n=144)$ w porównaniu do krajów południowych ( $\mathrm{n}=31$ ), a współczynnik zgonów ma taki sam rozkład (11). Porównując poszczególne kraje położone na północ od równika, współczynnik zachorowalności był znacznie niższy w krajach z obowiązkową szczepionką BCG ( $\mathrm{n}=109)$ w porównaniu do krajów bez obowiązku szczepienia ( $\mathrm{n}=35)$, a współczynnik zgonów charakteryzował się taką samą tendencją (11). Biorąc pod uwagę Europę, średnia liczba przypadków zachorowań na COVID-19 w populacji jest znacznie niższa w krajach europejskich, w których ludność była szczepiona BCG (n 
measures, cultural differences, public awareness, international trade relations, climate, and exposure to ultraviolet light (11).

The study assessing COVID-19 data of 4 April 2020 in various countries was conducted in India. Countries where the number of cases was higher than 1,000 with the policy of mandatory BCG vaccination and lower incidence of COVID-19 (for example India, Brazil) were selected for the analysis (13). The author suggests that not BCG vaccination itself, but the incidence of Mycobacterium tuberculosis and nontuberculous mycobacterial infections may reduce COVID-19 mortality. Latent mycobacterial infections can potentially have a protective effect (13). This does not necessarily mean that BCG does not give such an effect because it can affect the immune system like a latent infection. The vaccine effect cannot be separated from the effect of latent Mycobacterium tuberculosis infection, because vaccinations are usually carried out in mass in countries with high tuberculosis incidence and with a high percentage of the population infected with Mycobacterium tuberculosis.

Although BCG vaccination increases immunity of the body, it is certainly not the main factor contributing to lower morbidity and mortality from this disease. As mentioned before, there are many factors which may influence the variation of the disease and mortality rate. These are: genes in the population, age, concomitant accompanying diseases (for instance cardiovascular diseases, diabetes, rheumatoid arthritis, chronic respiratory diseases, HIV infection), and virulence of SARS-CoV-2 strains circulating in different regions. Moreover, the level of health care, the strategy of testing the presence of the virus, reliability of case reporting, reaction to the epidemic and its stage in different countries, differences in cultural norms, the level of citizens' compliance with restrictions on social isolation, the type of M. bovis strain in vaccine (early or late, probable differences in the strength of the evoked immune response after vaccination) or migration are enumerated as important factors $(8,13,14)$. Kumar claims that currently, due to lack of data from clinical trials, BCG vaccine should not be recommended to fight against COVID-19 (14).

A retrospective study conducted in Japan on 28 March 2020 assessed life expectancy, average temperature in the country in February and March and the possible vaccination effect on the spread of the COVID-19 epidemic. 136 countries were included in the study. As life expectancy measure proved to be a stronger predictor than temperature, countries with an average life expectancy greater than 78 years were qualified for further analysis. The study showed that the incidence and mortality (per million people) due to COVID-19 is lower in countries where BCG
=25) $\mathrm{w}$ porównaniu do krajów europejskich, w których nie wykonano takich szczepień $(n=26)$ (11).

Inne czynniki wymienione $\mathrm{w}$ badaniu mogące, poza szczepieniem BCG, wpływać na zachorowalność i umieralność na COVID-19 to: gęstość zaludnienia, środki izolacji, różnice kulturowe, świadomość społeczna, międzynarodowe stosunki handlowe, klimat oraz ekspozycja na światło ultrafioletowe (11).

Badanie oceniające dane dotyczące COVID-19 $\mathrm{z}$ dnia 04.04.2020 r. w różnych krajach przeprowadzono w Indiach. Do analizy wybrano kraje, gdzie liczba przypadków była większa niż 1000 z polityką obowiązkowego szczepienia BCG i mniejszą zachorowalnością na COVID-19 (np. Indie, Brazylia) (13). Autor sugeruje, że nie samo szczepienie BCG, a częstość zakażeń prątkiem gruźlicy i prątkami niegruźliczymi mogą zmniejszać umieralność na COVID-19. Utajone zakażenia prątkami mogą potencjalnie mieć efekt ochronny (13). Nie musi to oznaczać, że BCG takiego efektu nie daje, ponieważ może działać na układ immunologiczny podobnie jak utajone zakażenie. Efektu szczepionki nie da się oddzielić od wpływu latentnego zakażenia prątkiem gruźlicy, ponieważ szczepienia zwykle wykonywane są masowo w krajach o dużej zapadalności na gruźlicę i z dużym odsetkiem populacji zakażonej Mycobacterium tuberculosis.

Mimo że szczepienie BCG zwiększa odporność organizmu i może przez to umożliwiać lepszą odpowiedź organizmu na COVID-19, z pewnością nie jest głównym czynnikiem przyczyniającym się do niższej zachorowalności i umieralności na tę chorobę. Jak wspomniano, na zróżnicowanie współczynnika umieralności mogą wpływać inne czynniki, takie jak geny w populacji, wiek, współistniejące choroby towarzyszące (np. choroby układu sercowo-naczyniowego, cukrzyca, reumatoidalne zapalenie stawów, przewlekłe choroby układu oddechowego, zakażenie wirusem HIV) i zjadliwość szczepów wirusa SARS-CoV-2 krążących w różnych regionach. Wskazuje się również na wpływ poziomu opieki zdrowotnej, strategii testowania obecności wirusa, rzetelności raportowania przypadków, reakcji kraju na epidemię i jej stadium w różnych krajach, różnic w normach kulturowych, poziomu przestrzegania przez obywateli restrykcji odnośnie do izolacji społecznej, rodzaju szczepu M. bovis w szczepionce (wczesny lub późny, prawdopodobne związane z tym różnice w sile wywoływanej odpowiedzi immunologicznej po szczepieniu) czy migracji $(8,13,14)$. Kumar uważa, że z powodu braku danych pochodzących z badań klinicznych, szczepionka BCG nie powinna być rekomendowana do walki z COVID-19 (14).

Badanie retrospektywne $\mathrm{z}$ danych $\mathrm{z}$ dnia 28.03.2020 r. przeprowadzone w Japonii oceniło długość życia, średnią temperaturę w kraju w lutym i marcu oraz potencjalny efekt szczepienia na szerzenie się epidemii 
vaccination is currently performed compared to countries where vaccination is recommended to some people and where compulsory tuberculosis vaccination programs have never been introduced (15).

The authors hypothesized that protective effect of the vaccine means that it significantly reduces the risk of developing an infection after being exposed to the virus SARS-CoV-2, whereas it does not decrease the mortality rate or inhibits the progression of the disease after infection (15).

Age is an important risk factor for SARS-CoV-2 infection. It is closely correlated with the income of individual countries and the quality of medical care. Higher income and better healthcare can reduce the risk of disease and mortality rate (15). Regarding the relationship between age and mortality from COVID-19, protection after BCG vaccination may diminish over time and may contribute to higher mortality in older populations (15). The average temperature shows a small correlation with the risk of infection and mortality from COVID-19 (15).

Countries from group $\mathrm{B}$, in which compulsory BCG vaccinations were abandoned, are heterogeneous in terms of the years when compulsory vaccination was introduced and suspended. Also, they used the same vaccine strain (15). For that matter, in group A (still covered by the compulsory BCG vaccination program) there are differences between vaccination coverage levels in different countries (for example African countries where vaccination is compulsory, but the coverage is not necessarily high, which may distort results) (15). However, the analysis of countries where life expectancy is over 78 years excluded most African countries, which did not significantly affect the results (15). The spread of COVID-19 among African countries was relatively late compared to others continents. Thus, it may be necessary to carry out similar analyzes taking into account the coverage ratio after the further spread of the disease (15).

The study was conducted in the midst of the epidemic in most countries, so that the data presented should be interpreted with caution because it may change rapidly (15). Further analysis of the impact of BCG vaccination on the morbidity and mortality from COVID-19 are needed. Variables, like BCG strain, time, number of vaccinations, as well as other vaccinations, should be taken into account. It is also worth looking for a link between the age of BCG vaccination and the risk of infection, as well as the severity and mortality rate.

Another study evaluated demographic, economic, and different pandemic stages in individual countries. It shows that there is no statistically significant difference in mortality rate between countries which has BCG vaccination schedule (or had such schedule
COVID-19. W badaniu uwzględniono 136 krajów. Ponieważ miernik przewidywanej długości życia okazał się silniejszym predyktorem niż temperatura, do dalszej analizy zakwalifikowano państwa, w których średnia długość życia była większa niż 78 lat. Badanie ukazało, że w krajach, w których szczepienie BCG jest aktualnie wykonywane, zapadalność i umieralność (na milion osób) z powodu COVID-19 jest niższa zarówno w stosunku do krajów, gdzie szczepienie jest zalecane niektórym osobom, jak i tych, gdzie nigdy nie było wprowadzonych programów obowiązkowych szczepień na gruźlicę (15). Autorzy postawili hipotezę, że działanie ochronne szczepionki, jeśli w ogóle istnieje, polega raczej na znacznym zmniejszeniu ryzyka rozwoju zakażenia po ekspozycji na wirusa SARS-CoV-2 niż na zmniejszeniu wskaźnika umieralności lub na hamowaniu progresji choroby po infekcji (15).

Wiek jest istotnym czynnikiem ryzyka zakażenia SARS-CoV-2. Jest on ściśle skorelowany $z$ dochodem w poszczególnych krajach i jakością opieki medycznej. Wyższy dochód i lepsza opieka medyczna mogą zmniejszyć ryzyko zachorowania i umieralność na chorobę (15). W relacji między wiekiem a umieralnością na COVID-19, ochrona po szczepieniu BCG może słabnąć wraz z upływem czasu od szczepienia i może potencjalnie przyczynić się w pewnym stopniu do wyższej umieralności w populacjach starszych (15). Średnia temperatura z kolei wykazuje niewielką korelację z ryzykiem infekcji i umieralnością na COVID-19 (15).

Kraje grupy B, w których zrezygnowano z obowiązkowych szczepień BCG, są heterogeniczne pod względem lat, kiedy wprowadzono i wstrzymano obowiązkowe szczepienie oraz pod względem szczepu szczepionki (15). Również w grupie A (wciąż objętych programem obowiązkowych szczepień BCG) występują różnice pomiędzy poziomami zasięgu szczepień w różnych krajach (np. kraje afrykańskie, gdzie szczepienia są obowiązkowe, ale zasięg niekoniecznie wysoki, co może zniekształcać wyniki) (15). Jednak analiza krajów, gdzie długość życia wynosi powyżej 78 lat, wykluczyła większość krajów afrykańskich, co nie wpłynęło znacząco na wyniki (15). Rozpoczęcie rozprzestrzeniania się COVID-19 pośród krajów afrykańskich nastąpiło stosunkowo późno w porównaniu do innych kontynentów, więc może być konieczne przeprowadzenie podobnych analiz przy uwzględnieniu wskaźnika zasięgu po dalszym rozprzestrzenianiu się choroby (15).

Badanie prowadzone było w środku epidemii większości krajów, przez co przedstawiane dane szybko mogą ulec zmianie oraz powinny być one interpretowane z ostrożnością (15). Potrzebne są dalsze analizy wpływu szczepienia BCG na zachorowalność i umieralność na COVID-19. Należy ocenić zmienne, jak na przykład szczep BCG, czas i liczba szczepień oraz wykonywanie innych szczepień. Warto również poszukać 
in the past) compared to countries that have never had such a program (16). Wealthy countries as well as those with at least 1,000 COVID-19 cases with a population of over 1 million have been reported. The population that has been previously shown to use BCG-induced heterologous immunity is limited to the pediatric population which is mainly asymptomatic. Despite the fact that every effort has been made to avoid as many factors as possible that could change the result, some still remain: difference in mortality among men comparing to women (which may affect the overall mortality rate in countries with different demographic structures), type of bacterial strain in the vaccine, genetic factors - susceptibility to diseases, genetic differences in expression of the angiotensin type 2 converting enzyme receptor or CCL2 genes (ligand 2 chemokine gene) and MBL (mannose binding lectin) that can affect SARS-CoV-2 susceptibility (16). Due to the presence of many other factors affecting morbidity and mortality, there is a possibility of changes in the results of the analysis. Statistically significant differences seemed to disappear after taking into account other factors. Nevertheless, it has been pointed out that the immunostimulatory potential of BCG vaccine may be useful in the development of future vaccines or other preventive measures (16).

Mortality from COVID-19 was also higher in countries in which universal BCG vaccination was discontinued more than 20 years ago and in countries that regularly or temporarily used the Danish BCG strain (17). BCG strains that appear to be associated with lower mortality rate from COVID-19 (from Japan, Russia) are early strains, while BCG strain from Denmark that appears to induce less protection against COVID-19 is a late strain (17). Late strains lost the expression of several membrane proteins (MPB64, MPB70 and MPB83) and do not have lipids associated with the cell wall, including methoxymycolate. Early Japanese and Russian strains contain a much larger number of bacteria than late strains. Japanese BCG is more effective than Danish BCG in inducing and producing both $\mathrm{T}$ lymphocyte and pro-inflammatory cytokines (17). Data from both Finland and Australia do not support the hypothesis that early BCG strains reduce COVID-19 morbidity and mortality. In these countries, universal BCG vaccination programs were discontinued several years ago (in 2006 in Finland and in the mid-1980s in Australia), but they show low mortality per million inhabitants compared to countries where BCG vaccination is compulsory. BCG vaccination, even if it contributes to lowering COVID-19 mortality, is definitely not the only factor. It is pointed out that in both countries there are very good health care systems and low population density (17). powiązania pomiędzy wiekiem szczepienia na BCG a ryzykiem infekcji oraz ciężkością przebiegu i umieralnością na nią.

W innym badaniu uwzględniającym różnice demograficzne, gospodarcze i różne etapy pandemii w ocenianych krajach stwierdzono, że nie ma statystycznie istotnej różnicy w umieralności między krajami, w których obowiązuje obecnie lub obowiązywała wcześniejsza polityka szczepień BCG w porównaniu z krajami, które nigdy nie miały takiego programu (16). Uwzględniono zamożne kraje i gdzie odnotowano co najmniej 1000 przypadków COVID-19 i o liczbie mieszkańców powyżej 1 miliona. Populacja, dla której wcześniej wykazano, że korzysta z odporności heterologicznej indukowanej przez BCG, jest ograniczona do populacji pediatrycznej, która głównie choruje bezobjawowo. Chociaż dołożono wszelkich starań, aby uniknąć jak największej liczby czynników mogących zmienić wynik, niektóre nadal pozostały: różnica w umieralności większa w populacji mężczyzn niż w populacji kobiet (co może mieć wpływ na ogólną umieralność w krajach o odmiennej strukturze demograficznej), rodzaj szczepu bakteryjnego w szczepionce, czynniki genetyczne podatność na choroby, różnice genetyczne w ekspresji receptora enzymu konwertującego angiotensynę typu 2 lub genów CCL2 (gen ligandu 2 chemokiny) i MBL (lektyny wiążącej mannozę), które mogą wpływać na podatność na SARS-CoV-2 (16). Wskazano na możliwość zmian w wynikach analizy ze względu na obecność wielu innych czynników wpływających na zachorowalność i umieralność. Różnice istotne statystycznie wydawały się znikać po uwzględnieniu $\mathrm{w}$ analizie innych czynników. Niemniej jednak zaznaczono, że potencjał immunostymulujący szczepionki BCG może okazać się przydatny $\mathrm{w}$ opracowywaniu przyszłych szczepionek lub innych środków profilaktycznych (16).

Umieralność z powodu COVID-19 była również wyższa w krajach, w których powszechne szczepienia BCG przerwano ponad 20 lat temu oraz w krajach, które regularnie lub tymczasowo stosowały duński szczep BCG (17). Szczepy BCG, które wydają się być związane z niższą umieralnością COVID-19 (z Japonii, Rosji) są szczepami wczesnymi, podczas gdy szczep BCG z Danii, który wydaje się indukować mniejszą ochronę przed COVID-19, jest szczepem późnym (17). Późne szczepy utraciły ekspresję kilku białek błonowych (MPB64, MPB70 i MPB83) oraz nie posiadają lipidów związanych ze ścianą komórkową, w tym metoksymykolanu. Wczesne szczepy japońskie i rosyjskie zawierają znacznie większą liczbę bakterii niż szczepy późne. BCG japoński jest bardziej skuteczny niż BCG duński w indukowaniu produkcji limfocytów $\mathrm{T}$ i prozapalnych cytokin (17). Dane zarówno z Finlandii, jak i Australii nie podtrzymują hipotezy twierdzącej, że wczesne szczepy BCG zmniejszają zachorowalność i umieralność z po- 


\section{Effect of Mycobacterium tuberculosis infection on COVID-19}

A study carried out in Shenyang (China) at the turn of January and February 2020 assessed whether tuberculosis (both active and latent tuberculosis infection) is a significant risk factor in the development of SARS-CoV-2 infection. It was noted that latent infection in approximately $25 \%$ of the world population may be a risk factor for SARS-CoV-2 infection and severe pneumonia due to COVID-19 $(18,19)$. The study conducted in China showed a higher prevalence of mycobacterial infection (36\%) compared to other concomitant diseases such as diabetes $(25 \%)$, hypertension $(22 \%)$, coronary artery disease $(8 \%)$, COPD (5\%) (19). 86 cases of suspected COVID-19 infection were examined and 36 cases were confirmed. The study sample included $27 \mathrm{mild} /$ moderate cases and 9 severe/critical cases (25\%). In 7 out of 9 severe cases IGRA test result was positive. In the study group in total, 13 cases presented IGRA positive test result (36.11\%), including 3 active tuberculosis infections among COVID-19 positive patients after further diagnosis. Mycobacterium tuberculosis infection was more common in patients with COVID-19 than with bacterial $(20 \%)$ and other viral $(16.13 \%)$ pneumonia. It was found that in mild and moderate cases of COVID-19 pneumonia, 22\% of patients were infected with Mycobacterium tuberculosis while in severe and critical cases the incidence of the infection increased to $78 \%$ (19). Co-infection of Mycobacterium tuberculosis with SARS-CoV-2 was associated with a more severe course and faster development of infection (19). Considering the fact that tuberculosis is an important factor contributing to the aggravation of COVID-19, isolation of patients with tuberculosis may be a major factor in reducing the incidence of severe COVID-19 $(18,19)$.

Therefore, the status of Mycobacterium tuberculosis infection should be routinely checked among COVID-19 patients (19). The protective effect of the tuberculosis vaccine decreases with age (4). It can be concluded that reducing tuberculosis incidence as a result of BCG vaccinations, the use of antituberculosis drugs, and the isolation of patients can indirectly reduce COVID-19 morbidity and mortality.

\section{Further studies which might explain the relationship between BCG and COVID-19 and current recommendations}

The World Health Organization does not currently recommend BCG vaccination to prevent COVID-19 due to the lack of sufficient evidence supporting the hypothesis. WHO still recommends vaccinating newborns with BCG vaccine in countries with high tuberculosis incidence and allows the use of BCG wodu COVID-19. Kraje te zaprzestały powszechnych programów szczepień BCG kilkanaście lat temu (2006 r. w Finlandii i od połowy lat 80-tych w Australii), ale wykazują niską umieralność na milion mieszkańców w porównaniu z krajami, w których szczepienia BCG są obowiązkowe. Szczepienie BCG, nawet jeśli przyczynia się do obniżenia umieralności z powodu COVID-19, wyraźnie nie jest jedynym czynnikiem. Wskazuje się na bardzo dobrą opiekę zdrowotną w obu krajach i niską gęstość zaludnienia (17).

\section{Wpływ zakażenia Mycobacterium tuberculosis na przebieg COVID-19}

W badaniu przeprowadzonym w Shenyang (Chiny) na przełomie stycznia i lutego 2020 r. oceniano, czy gruźlica (zarówno aktywne, jak i utajone zakażenie prątkiem gruźlicy) jest istotnym czynnikiem ryzyka w rozwoju infekcji SARS-CoV-2. Zwrócono uwagę, że utajone zakażenie u około $25 \%$ światowej populacji może być czynnikiem ryzyka zakażenia SARS-CoV-2 i ciężkiego zapalenia płuc z powodu COVID-19 $(18,19)$. Badanie przeprowadzone w Chinach wskazywało na częstsze zakażenie prątkiem, wynoszące $36 \%$, w stosunku do innych chorób towarzyszących, takich jak cukrzyca $(25 \%)$, nadciśnienie tętnicze $(22 \%)$, choroba naczyń wieńcowych (8\%), POChP (5\%) (19). Przebadano 86 przypadków podejrzanych o zakażenie COVID-19, gdzie potwierdzono 36 zachorowań. W próbie badawczej znalazło się 27 łagodnych/umiarkowanych przypadków i 9 ciężkich/krytycznych (25\%). U 7 na 9 ciężkich przypadków wynik testu IGRA był dodatni. W całej grupie badanej łącznie 13 osób miało wynik IGRA + (36,11\%), w tym u 3 chorych na COVID-19 po dalszej diagnostyce stwierdzono aktywną formę gruźlicy. Zakażenie prątkiem gruźlicy diagnozowano częściej w przypadku pacjentów z COVID-19 niż z bakteryjnym (20\%) i innym wirusowym $(16,13 \%)$ zapaleniem płuc. Porównując stadium gruźlicy wśród przypadków zapalenia płuc spowodowanych COVID-19 stwierdzono, że w przypadkach lekkich i umiarkowanych $22 \%$ pacjentów jest zakażonych prątkiem, natomiast $\mathrm{w}$ przypadkach ciężkich i krytycznych częstość zakażenia wzrosła do 78\% (19). Współinfekcja prątka gruźlicy z SARSCoV-2 wiązała się z cięższym przebiegiem i szybszym rozwojem zakażenia (19). Biorąc pod uwagę, że gruźlica jest istotnym czynnikiem sprzyjającym pogorszeniu przebiegu COVID-19, izolacja chorych z gruźlicą może być istotnym czynnikiem zmniejszającym występowanie ciężkich przypadków COVID-19 $(18,19)$.

Status infekcji prątkiem gruźlicy powinien być więc rutynowo sprawdzany pośród pacjentów z COVID-19 (19). Działanie ochronne szczepionki przeciwko gruźlicy zmniejsza się w starszym wieku (4). Na podstawie powyższych danych można wnioskować, że zmniejszenie zapadalności na gruźlicę w wyniku szczepień BCG, 
vaccine to protect against COVID-19 only in clinical studies (20).

The Science Magazine provides information about a study started in the Netherlands involving 1,000 healthcare professionals from eight hospitals who will receive a BCG vaccine or a placebo. The mycobacterial tuberculosis vaccine was chosen because according to studies by P. Aaby and C. S. Benn from GuineaBissau it increases the ability to fight other infections as well. In their opinion, the vaccine protects against about $30 \%$ of infections caused by other pathogens (including viruses) in the first year after vaccination $(1,12,21)$.

Similar studies will be done at the universities of Melbourne and Exeter (in Exeter also on the elderly). Researchers from the Max Planck Institute for Infection Biology in Berlin have announced that they will start a similar trial on healthcare workers and elderly people, using genetically modified version of the BCG vaccine (the recombinant vaccine strain VPM1002) $(1,12,21)$.

The answer to the question of how long the heterologous immune response after BCG vaccination remains is essential. It would be significant in the selection of the optimal vaccination time (1).

Some researchers indicate that we should remain sceptical about both general statements about enhancing immunity after BCG vaccination and specifically the protective effect against SARS-CoV-2. Thus, they claim that it is better to invest limited resources in other confirmed preventive measures (21). It is worth to remember that BCG vaccine should not be given to people in the active phase of severe disease (as a live vaccine), because it might not work quickly enough and could disrupt treatment results.

It should be noted that the massive use of BCG vaccine for protection against COVID-19 may lead to reduction of reserves and lack of protection against tuberculosis of children from high risk areas and depletion of its resources for patients with bladder cancer $(1,22)$. Moreover, it is unlikely that despite the modulating effect on the immune system, the BCG vaccine which was given to children several decades ago will significantly improve COVID-19 morbidity and mortality rates among them. In the absence of evidence, the fact of being vaccinated in childhood can create a false sense of security and the abandonment of sanitary discipline and social isolation. Full safety monitoring in randomized trials is necessary to protect against the possibility of exacerbating COVID-19 by BCG's increased immunity in some patients with severe course of disease (22). stosowaniu leków przeciwgruźliczych i izolacji chorych może pośrednio zmniejszyć zachorowalność i umieralność z powodu COVID-19.

\section{Dalsze badania mające wyjaśnić zależność między BCG a COVID-19 i aktualne zalecenia}

Wobec braku wystarczających dowodów potwierdzających postawioną hipotezę Światowa Organizacja Zdrowia nie zaleca $\mathrm{w}$ obecnym momencie szczepienia BCG w celu zapobiegania COVID-19. WHO nadal zaleca szczepienia noworodków szczepionką BCG w krajach o wysokiej zapadalności na gruźlicę, a użycie szczepionki BCG w celu ochrony przed COVID-19 dopuszcza tylko w badaniach klinicznych (20).

Czasopismo naukowe "Science" podaje informację o badaniu rozpoczętym w Holandii, w którym weźmie udział 1000 pracowników służby zdrowia z ośmiu szpitali, którzy otrzymają szczepionkę BCG lub placebo. Wybrano szczepionkę przeciw prątkowi gruźlicy ze względu na to, iż powoduje ona wzrost zdolności walki również z innymi infekcjami według badań $P$. Aaby i C. S. Benn z Gwinei Bissau. Ich zdaniem szczepionka chroni przed około $30 \%$ infekcji wywołanych innymi patogenami (w tym wirusami) przez pierwszy rok po zaszczepieniu $(1,12,21)$.

Podobne prace zostaną wykonane na uniwersytetach w miastach Melbourne i Exeter (w Exeter również na populacji osób starszych). Badacze z Max Planck Institute for Infection Biology z Berlina ogłosili, iż rozpoczną podobną próbę na pracownikach służby zdrowia i osobach starszych w oparciu o genetycznie modyfikowaną wersję szczepionki na BCG (rekombinowany szczep szczepionkowy VPM1002) $(1,12,21)$.

Ważną kwestią pozostaje odpowiedź na pytanie, jak długo utrzymuje się heterologiczna odpowiedź układu odpornościowego po szczepieniu BCG. Miałoby to znaczenie w ewentualnym wyborze optymalnego czasu szczepienia (1).

Niektórzy badacze wskazują, że zarówno, jeśli chodzi o ogólne stwierdzenia o wzmocnieniu odporności po szczepieniu BCG, jak i konkretnie o efekcie ochronnym w stosunku do SARS-CoV-2 należy pozostać sceptycznym i lepiej zainwestować ograniczone zasoby w inne potwierdzone środki zapobiegawcze (21). Warto pamiętać, że szczepionki BCG jako szczepionki żywej nie należałoby podawać osobom w aktywnej fazie ciężkiej choroby, ponieważ nie zadziałałaby odpowiednio szybko i mogłaby zakłócić wyniki leczenia.

Należy zauważyć, iż masowe stosowanie szczepionki BCG w celu ochrony przed COVID-19 może doprowadzić do wyczerpania zapasów i braku ochrony przed gruźlicą dzieci z obszarów wysokiego ryzyka oraz wyczerpanie jej zasobów dla pacjentów z rakiem pęcherza moczowego $(1,22)$. Poza tym jest mało prawdopodobne, mimo modulującego wpływu szczepionki 


\section{CONCLUSIONS}

At present there is no sufficient evidence to firmly confirm or deny the hypothesis of COVID-19 reduction in morbidity and mortality in countries maintaining compulsory BCG vaccination. The fact of increasing resistance to various viral infections after BCG vaccination does not automatically confirm its protective effect on SARS-CoV-2 infection. Although the conclusions of the analysis of epidemiological data are extremely interesting, it can be disturbed by other factors that should be taken into account in further analysis. Furthermore, the analyses differ in terms of conclusions and recommendations. If it turned out that the BCG vaccine actually provides non-specific protection against COVID-19, it would become an important tool in the fight against the new disease until a specific vaccine is developed. The results of initiated clinical studies will certainly explain this potential relationship. Due to the lack of an unambiguous answer to the hypothesis, the World Health Organization does not change the indications for the use of BCG vaccine at present and recommends its administration to newborns from areas with a higher incidence of tuberculosis.

\section{REFERENCES}

1. Redelman-Sidi G. Could BCG be used to protect against COVID-19? Nat Rev Urol 2020. doi: 10.1038/s41585-020-0325-9.

2. Arts RJW, Moorlag SJCFM, Novakovic B et al. BCG vaccination protects against experimental viral infection in humans through the induction of cytokines associated with trained immunity. Cell Host Microbe 2018;23(1):89-100.e5. doi: 10.1016/j. chom.2017.12.010.

3. Ayoub BM. COVID-19 vaccination clinical trials should consider multiple doses of BCG. Die Pharmazie 2020;75(4):159. https://doi.org/10.1691/ ph.2020.0444

4. Gyssens IC, Netea MG. Heterologous effects of vaccination and trained immunity. Clin Microbiol Infect 2019;25(12):1457-1458. doi: 10.1016/j. cmi.2019.05.024

5. De Castro MJ, Pardo-Seco J, Martinón-Torres F. Nonspecific (heterologous) protection of neonatal BCG vaccination against hospitalization due to respiratory infection and sepsis. Clin Infect Dis 2015;60(11):1611-9. doi: 10.1093/cid/civ144.

6. Covián C, Fernández-Fierro A, Retamal-Díaz $\mathrm{A}$ et al. BCG-induced cross-protection and development of trained immunity: implication for vaccine design. Front Immunol 2019;10:2806. doi: 10.3389/fimmu.2019.02806.
BCG na układ odpornościowy, że podana kilkadziesiąt lat temu w dzieciństwie znacząco poprawi wskaźniki zachorowalności i umieralności z powodu COVID-19. Jej stosowanie przy braku dowodów może wywołać fałszywe poczucie bezpieczeństwa i zaprzestanie zachowywania rygorów sanitarnych i izolacji społecznej. Konieczne jest pełne monitorowanie bezpieczeństwa w randomizowanych badaniach, aby uchronić się przed możliwością, że zwiększenie odporności przez BCG zaostrzy COVID-19 u niektórych pacjentów z ciężkim przebiegiem choroby (22).

\section{WNIOSKI}

W obecnej chwili nie ma wystarczających dowodów, by z całą pewnością potwierdzić lub zaprzeczyć postawionej hipotezie obniżenia zachorowalności i umieralności z powodu COVID-19 w krajach utrzymujących obowiązkowe szczepienie BCG. Fakt zwiększania odporności na różne zakażenia wirusowe po szczepieniu BCG nie potwierdza automatycznie jego ochronnego wpływu na zakażenie koronawirusem SARS-CoV-2. Mimo że wnioski z analizy danych epidemiologicznych są niezwykle interesujące, mogą być zakłócone przez inne czynniki, które należy wziąć pod uwagę $\mathrm{w}$ dalszych analizach. Co więcej, analizy różnią się między sobą, jeśli chodzi o wnioski i zalecenia. Jeśli okazałoby się, że szczepionka BCG faktycznie zapewnia niespecyficzną ochronę przed COVID-19, stałaby się istotnym narzędziem walki z nową chorobą do czasu opracowania specyficznej szczepionki. Wyniki rozpoczętych badań klinicznych z pewnością wyjaśnią tę potencjalną zależność. $Z$ powodu braku jednoznacznej odpowiedzi na postawioną hipotezę, w obecnej chwili Światowa Organizacja Zdrowia nie zmienia wskazań do stosowania szczepionki BCG i zaleca jej podawanie noworodkom $\mathrm{z}$ terenów o wyższej zachorowalności na gruźlicę.

7. Moorlag SJCFM, Arts RJW, van Crevel R et al. Non-specific effects of BCG vaccine on viral infections. Clin Microbiol Infect 2019;25(12):14731478. doi: 10.1016/j.cmi.2019.04.020.

8. Miller A, Reandelar MJ, Fasciglione $\mathrm{K}$ et al. Correlation between universal BCG vaccination policy and reduced morbidity and mortality for COVID-19: an epidemiological study. [preprint, 2020] https://doi.org/10.1101/2020.03.24.20042937

9. Gursel M, Gursel I. Is global BCG vaccinationinduced trained immunity relevant to the progression of SARS-CoV-2 pandemic? Allergy 2020;10.1111/all.14345 Apr 27. doi: 10.1111/ all.14345. [Epub ahead of print]

10. Krishna K, Dasgupta N, Das G. Mechanism of heterologous resistance of BCG to COVID-19. [preprint, 2020] doi:10.31219/osf.io/f32pz. 
11. Ozdemir C, Kucuksezer UC, Tamay ZU. Is BCG vaccination effecting the spread and severity of COVID-19? Allergy 2020;10.1111/all.14344 Apr 24. doi: 10.1111/all.14344. [Epub ahead of print]

12. De Vrieze J. Can a century-old TB vaccine steel the immune system against the new coronavirus? Science (2020) [https://www.sciencemag.org/ news/2020/03/can-century-old-tb-vaccine-steelimmune-system-against-new-coronavirus\#] [dostęp 08.05.2020 r.]

13. Singh S. BCG vaccines may not reduce COVID-19 mortality rates. [preprint, 2020] doi:10.1101/2020.0 4.11.20062232.

14. Kumar J, Meena J. Demystifying BCG vaccine and COVID-19 relationship. Indian Pediatr 2020 Apr 30. pii: S097475591600168. [Epub ahead of print]

15. Sala G, Miyakawa T. Association of BCG vaccination policy with prevalence and mortality of COVID-19. [preprint, 2020] doi:10.1101/2020.0 3.30.20048165.

16. Paredes JA, Garduño V, Torres J. COVID-19 Related Mortality: Is the BCG vaccine truly effective? [preprint, 2020] https://doi.org/10.1101/2 020.05.01.20087411.

17. Miyasaka M. Is BCG vaccination causally related to reduced COVID-19 mortality? EMBO Mol Med. 2020 May 7. doi: 10.15252/emmm.202012661. [Epub ahead of print]

18. Maciel ELN, Gonçalves Júnior E, Dalcolmo MMP. Tuberculosis and coronavirus: what do we know?
Epidemiol Serv Saúde 2020;29(2):e2020128. https://doi.org/10.5123/s1679-49742020000200010

19. Chen Y, Wang Y, Fleming J et al. Active or latent tuberculosis increases susceptibility to COVID-19 and disease severity. [preprint, 2020] https://doi. org/10.1101/2020.03.10.20033795

20. WHO. Bacille Calmette-Guérin (BCG) vaccination and COVID-19. April 12, 2020. [https://www. who.int/news-room/commentaries/detail/bacillecalmette-gu\%C3\%A9rin-(bcg)-vaccination-andcovid-19] [dostęp 8.05.2020 r.]

21. Lawton G. Trials of BCG vaccine will test for COVID-19 protection. New Sci 2020;246(3280):9. doi: 10.1016/S0262-4079(20)30836-8.

22. Curtis N, Sparrow A, Ghebreyesus TA et al. Considering BCG vaccination to reduce the impact of COVID-19. Lancet 2020;395(10236):1545-1546. doi: 10.1016/S0140-6736(20)31025-4.

Received: 27.05.2020

Accepted for publication: 25.06.2020

Otrzymano: 27.05.2020 r.

Zaakceptowano do publikacji: 25.06.2020 r.

\section{Address for correspondence:}

Adres do korespondencji:

Chair and Department of Epidemiology and Clinical Research Methodology

Medical University of Lublin

Radziwiłłowska 11, 20-080 Lublin, Poland

tel. 814486375

e-mail: gabrysia.reka@gmail.com 